\title{
Acute Toxicity Test of Jernang Resin Extract (Daemonorops Draco Willd.) on Male White Rats Sprague Dawley Strain
}

\author{
Fidia Yunita ${ }^{1}$ Lavlinesia $^{1}$, Mursyid ${ }^{1}$ \\ Faculty of Agricultural Technology, Jambi University, Pondok Meja, Tribrata street Km 11, Jambi, Indonesia \\ E-mail: fidiayunita79@gmail.com
}

\begin{abstract}
This research aimed to determine the toxic effect and $\mathrm{LD}_{50}$ (Lethal Dose $_{50}$ ) value from jernang resin extract (Daemonorops Draco Willd.) on male white rats Sprague Dawley strain. This research was conducted using a Completely Randomized Design (CRD) with 25 male rats, divided into 5 groups. Every group consisted of 5 rats which given different dosage levels of $0,1000,2000,4000$, and $8000 \mathrm{mg} / \mathrm{kg} \mathrm{BW}$. The provision of a jernang resin extract pure was oral with using a single dose (once giving) and the observation was carried out for 14 days. The parameters observed were total consumption, weight increasing, clinical symptoms, $L D_{50}$ value, and macroscopic organ (liver and kidney) of rats. The results of the study showed that jernang resin extract did not provide a toxic effect on rats as seen from total consumption, weight increase, and clinical symptoms. Jernang resin extract with $8000 \mathrm{mg} / \mathrm{kg} \mathrm{BW}$ dose could be categorized as safe to eat because it tended to accelerate the growth of rats and did not cause harm rats metabolic organs. Macroscopic observation of the liver and kidneys showed there was no abnormalities and the organ's weight was still in the normal category.
\end{abstract}

Keywords - Jernang resin extract; white rats; acute toxicity

\section{INTRODUCTION}

Jernang (The dragon's blood) resin is a red resin from the secretion of jernang rattan fruit [1]. Jernang resin sticks to and covers the outside of the rattan fruit, where extraction is needed to obtain it. Jernang, known as dragon's blood palm, is one of the clumped dioecious types of rattan. Generally the use of rattanis part of the stemand jernanguse is the resin that found in the fruit [2].

Jernang is used in coloring raw materials in the ceramics, marble, stone, wood, paper, and pharmaceutical industries. The traditional use of jernang is for dysentery and wound medicine [3]. However, the use of jernang as food is still very small.

Jernang resin research has been carried out such as making jernang emulsion drinks, coloring agents for sausages, and coloring in ice cream. But food safety testing for the jernang resin (Daemonorops Draco Willd) type has never been done. Everything that is consumed by humans, both derived from vegetable and animal foods, contains a variety of beneficial substances and is needed by the body to carry out activities. But there are certain components that can sometimes cause undesirable conditions, such as symptoms of illness to death [4].

Flavonoid compounds are included in the phenolic group which acts as a secondary metabolite inhibiting toxin and the nervous system that works slowly. Flavonoid compounds in high doses that enter the body are actually dangerous and the adverse effects are more likely to occur than the benefits, even all chemicals will be toxic if not given proportionally [5]. This condition causes the need to do a toxicity test to determine the

negative biological effects resulting from the administration of a substance. One toxicity test is an acute toxicity test to know the Lethal Dose $\left(\mathrm{LD}_{50}\right)$ value.

The $\mathrm{LD}_{50}$ value is a statistically derived quantity to express a single dose of a compound that is thought to be deadly or have a significant toxic effect on $50 \%$ of experimental animals after treatment. $\mathrm{LD}_{50}$ is a quantitative benchmark that is often used to express lethal dose ranges [6]. This acute toxicity is carried out by in vivo testing using general laboratory animals. In vivo toxicity testing is needed because it has several advantages including data obtained related to normal physiological and biochemical conditions and the results of in vivo testing of experimental animals can be interpolated to humans or as toxicological prediction materials for domestic animals and livestock [7]. The data from the acute toxicity test results were obtained by conducting several analyzes including analysis of body weight, total consumption, clinical symptoms, LD50 values, and analysis of organ damage. The purpose of this study was to determine the toxic effects and determine the criteria for the degree of toxicity of jernang resin extracts (Daemonorops draco Willd.) on male white rats Sprague dawley strain. 


\section{MAterial AND Methods}

\section{A. Material}

The material used was jernang resin extract, male white rats Sprague dawley strain, standard feeding produced by PT. CJ Cheiljedang Feed Lampung, drinking water, VCO "Optima", wood dust, 70\% alcohol, and chloroform. The tools used are mouse cages, digital scales, glassware, surgical equipment, gastric tube, micropipette, masks, and gloves.

\section{B. Methods}

\section{a. Research Design and Statistical Analysis}

This study used a Completely Randomized Design (CRD) with the treatment of jernang resin extracts. The principle of acute toxicity testing is the provision of test material in the form of jernang resin ethyl acetate extract in several groups of test animals once during the test period with 5 dose levels, 0 (as a control), 1000, 2000, 4000, and $8000 \mathrm{mg} / \mathrm{kg}$ body weight. The data obtained in the form of quantitative and qualitative data.

Determination of the number of repetitions (number of rats in one group) was calculated based on the Federer's formula: $(\mathrm{n}-1)(\mathrm{t}-1) \geq 15$

Where $\mathrm{n}=$ the minimum number of repetitions of each treatment

$\mathrm{t}=$ number of treatments

The number of test animals used in each group is:

$$
\begin{aligned}
(\mathrm{n}-1)(\mathrm{t}-1) & \geq 15 \\
(\mathrm{n}-1)(5-1) & \geq 15 \\
(\mathrm{n}-1)(4) & \geq 15 \\
(4 \mathrm{n}-4) & \geq 15 \\
4 \mathrm{n} & \geq 19 \\
\mathrm{n} & \geq 4,75 \approx 5
\end{aligned}
$$

From the calculation results, the value of $n=4,75$ was fulfilled into 5, thus the number of replications or groups of rats in 1 treatment was 5 , so that the number of white rats used was 25 rats. The parameters observed after administration of jernang resin ethyl acetate extract from each rat were total consumption, body weight, clinical symptoms, and the number of animal deaths. This observation is carried out every day for 14 days, while for macroscopic analysis of organs especially in the liver and kidneys observed after surgery, which is on the 15 th day.

\section{b. Research procedure}

\section{Preparation of Jernang Resin Ethyl Acetate Extract Concentration}

The jernang ethyl acetate resin extract in the form of concentrated paste was dissolved with VCO before being given to rats. The average weight in the group of rats was converted at doses of each treatment starting from 1000, 2000, 4000 , and $8000 \mathrm{mg} / \mathrm{kg}$. The volume given to each rat is $6 \mathrm{ml}$ according to the capacity of the rat's stomach. Then for each dose is needed $30 \mathrm{ml}$ of liquid for 1 group of rats with adding $\mathrm{VCO}$ as a solvent for each jernang concentration.

\section{Cage Preparation}

The room used to place the cage was equipped with a fan and a metal rack to place the cage with three levels. Rat cages before use must be cleaned first by washing and drying with a cloth. White rats are held individually in plastic tubs measuring $410 \times 320 \times 130 \mathrm{~mm}^{3}$ by using a wire to cover the top of the cage. The cage is equipped with bottled water and a place to feed. The cage is covered with sawdust which is replaced every day to maintain environmental humidity. Provision of wood powder as much as 2-3 grams with a height of $5 \mathrm{~mm}$.

\section{Preparation of Experimental Animals [8]}

The male white Sprague Dawley strain used in this study was obtained from the Faculty of Medicine, Jambi University with the age of 2 months and bodyweight of 96-148 grams. The white rats were put in a plastic. White rats were adapted for 2 weeks before being treated with jernang resin ethyl acetate extract. The adaptation process aims to homogenize the bodyweight of rats and see their growth patterns in the new environment. During this adaptation, weighing and remaining rations were measured every day. The cage is also cleaned by washing it daily and dried using a cloth. After drying the cage is sprinkled with sawdust. Rations and drinking water were given in excess (ad libitum).

\section{Administration of Jernang Resin Extract [8]}

The provision of jernang resin extracts was done after the adaptation period that is on the 1 st day of observation. Rats must be fasted before being treated for 14 hours (drinking water was still given). After being satisfied, the rats were weighed and given a jernang resin extract that had been dissolved with VCO.In each group, jernang oral resin extracts were given in a single dose orally (bending) using a gastric sonde with several dosage levels, 0 (as a control), 1000, 2000, 4000 , and $8000 \mathrm{mg} / \mathrm{kg} \mathrm{BW}$. The volume of solution given as much as $6 \mathrm{ml}$ in each rat.Rationing again after 3-4 hours after giving the sample. Observations were made every day for 14 days precisely at 13.00 WIB.

\section{Observation Stage}

Observations were made every day for 14 days of total consumption, weight gain, and clinical symptoms. Every death that occurred during the observation period and at the end of the test was performed surgery for macroscopic organ observation by comparing the organs of rats treated with the controls. Liver and kidney organs in rats can be taken using surgical scissors. The purpose of the surgery is to examine macroscopic and microscopic organs of the body and to reveal damage to organ structures that can explain the symptoms of impaired function [9]. Organ observations are carried out macroscopically, so what is observed is the color and appearance of the organ and organ weight. The organs observed included: liver and kidney. 
c. Parameter Analysis

Total Consumption

Total consumption was also observed in this study, the way it is done is by weighing the rest of the standard ration given

\begin{tabular}{ccc}
\hline $\begin{array}{c}\text { Dose } \\
(\mathbf{m g} / \mathbf{k g ~ B W})\end{array}$ & $\begin{array}{c}\text { Total } \\
\text { Consumption }(\mathbf{g r})\end{array}$ & Weight Gain (gr) \\
\hline 0 (Control) & 155.61 & 19.60 \\
1000 & 138.20 & 17.45 \\
2000 & 154.72 & 18.60 \\
4000 & 161.71 & 22.40 \\
8000 & 223.95 & 29.20 \\
\hline
\end{tabular}

every day. Calculation of consumption patterns can be done with the formula:

Total consumption $=$ initial ration - remaining ration

\section{Rat Weight Increase}

Rat bodyweight was observed by weighing rats using a scale for experimental animals. This weighing is carried out every day, to see the effects that occur on the growth of rats starting from the beginning of the study until the end of the study.

\section{Observation of Clinical Symptoms}

Observation of test animals was carried out to determine the effect of giving jernang resin extracts to the activities and behavior of rats. These observations include activity, gastrointestinal, gastrourinary, and muscular nerves. Observation of the activities and behavior of rats was carried out for 14 days [10].

\section{Determination of $L D_{50}$ Value}

Determination of $\mathrm{LD}_{50}$ values was done by looking at data on the number of animals that die in each group of dose ratings used, to calculate $\mathrm{LD}_{50}$ values, one of the appropriate statistical methods is used. One of them is the Thomson and Weil method [11] with the formula:

LD50 $\log =\log D+d(f+1)$

For the LD50 range the formula is used:

LD50 $\log \pm 2$ d. $\delta \mathrm{f}$

Where :

$\mathrm{D}=$ the smallest dose used

$\mathrm{d}=$ logarithm of multiples of doses

$\mathrm{f}=\mathrm{a}$ factor in the table

$\delta f=a$ value in the table that depends on the values of $n$ and $\mathrm{k}$

\section{Macroscopic Observation of Organs in Rats}

This observation was carried out by weighing the organs and comparing the colors in the liver and kidneys given a dose of 0 (control) with rats given doses of 1000, 2000, 4000, and $8000 \mathrm{mg} / \mathrm{kg} \mathrm{BW}$.

\section{RESULT AND DISCUSSION}

\section{a. Total Consumption}

This total consumption is very closely related to the observations of body weight obtained (Table 1). Increased body weight showed an increase in total consumption in each group of rats. The decrease in rat feed consumption occurred on the 2nd day after the treatment was given. The graph of total rat consumption can be seen in Figure 1.

TABLE 1.

\section{Results Of Average Total CONSUMPTION AND WeIGHT GAIN OF RATS}

The decrease in total consumption was thought to be caused not by a toxic effect but by the response of the rat's body after administration of the treatment. This was evidenced by the total consumption that returned to normal on the 3rd day which was also marked by increased body weight of rats and less residual rations.

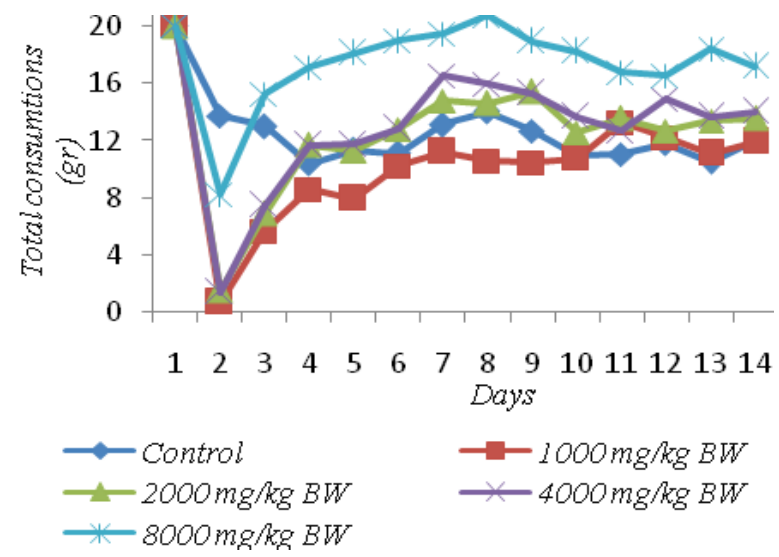

Fig 1. Changes in total consumption in rats for 14 days of observation after administration of jernang resin ethyl acetate extract

The difference in total consumption in white rats in this study was thought to be influenced by the bodyweight of each rat rather than from the treatment of doses of jernang resin extracts. The need for feed a rat daily is about $10 \%$ of its body weight, if the feed is dry [12].

\section{b. Body Weight of Rats}

The toxic effect of a compound is not only demonstrated by the mortality or the main changes observed in the toxicity test in the test animals but can also be illustrated by other changes such as its effect on feed consumption and body weight which is a multilevel response [13]. In this study, observations of the body weight of rats were carried out to determine changes in body weight which is one of the parameters of toxic effects. The results of weighing the average body weight of rats during the observation based on each treatment group different dose levels can be seen in Figure 2. 


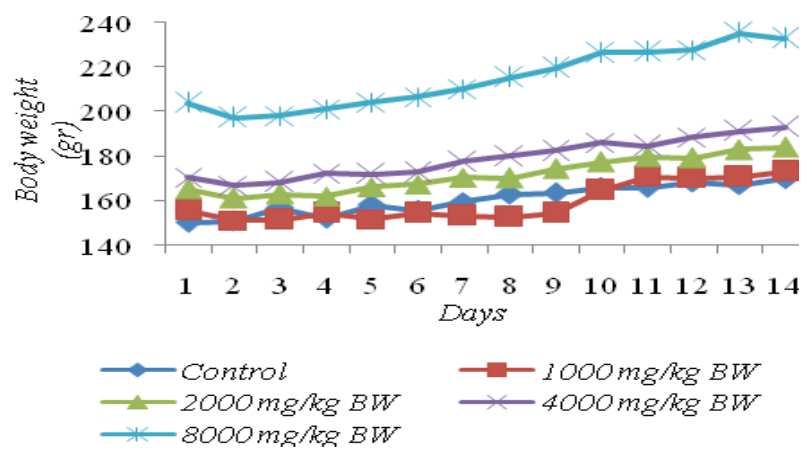

Fig 2. Changes in body weight of rats for 14 days of observation after administration of jernang resin ethyl acetate extract

Based on these data, an increase in the average body weight of rats were observed during the range of 1-6 grams per day. But on the second day in the group of rats given the dose treatment with levels of $1000-8000 \mathrm{mg} / \mathrm{kg}$ body weight decreased. The rat's body weight increased again on the $3^{\text {rd }}$ day until the last day of the observation. This condition shows that the decrease in the average body weight of rats was thought not to be caused by toxic effects but rather a form of

the process of adaptation to stress after administration of treatment.

\section{c. Clinical Symptoms}

Clinical symptoms are indications of the presence of unwanted health disorders, such as signs or characteristics of changes experienced by the body. Observation of signs of toxicity in rats is a qualitative observation made by looking at differences in behavior between test rats and control rats. The signs of toxicity observed include piloerection, convulation (convulsions), tremors (trembling), pain, earlobe response, changes in the eye, hyperactivity, hypersalivation, lacrimation, and death [14].

Another symptom that is also observed is gastrointestinal. Observations made on the gastrointestinal were seen from the results of each rat's feces by comparing the feces of the control rat and the dose treatment rat. From the observations (Table 2) it can be seen that the control group rats did not experience diarrhea, whereas in the treatment group rats doses of 1000 , 2000, 4000 and $8000 \mathrm{mg} / \mathrm{kg} \mathrm{BW}$ experienced diarrhea after 24 hours of administration of jernang resin extracts. Symptoms of diarrhea occur only for 1 day after the administration of the test sample and did not repeat the next day until the end of observation.

TABLE 2 .

CLINICAL SYMPTOMS IN EXPERIMENTAL ANIMALS FOR 14 DAYS OF OBSERVATION AFTER ADMINISTRATION OF JERNANG RESIN ETHYL ACETATE EXTRACT

\begin{tabular}{ccccc}
\hline \multirow{2}{*}{$\begin{array}{c}\text { Dosage (mg/kg body } \\
\text { weight) }\end{array}$} & Activity & Gastrointestinal & Gastrourinary & $\begin{array}{c}\text { Muscle } \\
\text { Nerves }\end{array}$ \\
\cline { 2 - 4 } & Normal & - & - & - \\
1000 & Normal & Diarrhea & - & - \\
2000 & Normal & Diarrhea & - & - \\
4000 & Normal & Diarrhea & - & - \\
8000 & Normal & Diarrhea * & - & - \\
\hline
\end{tabular}

Note: * symptoms occurred only after 24 hours of administration of jernang resin extracts

Gastrourinary observations or uncontrolled urination can be seen from the condition of the sawdust found in the rat cage. The results of observations after 24 hours of administration of jernang resin extracts were not found any of these signs, this was known from the condition of wood powder that was still dry and the absence of excess liquid from the cage. The observation was also continued the following day until the 14th day and no symptoms were found for gastrourinary.

Observations on muscle nerves can be seen from the behavior of rats undergoing convulsion (convulsions) and tremors (trembling). However, these conditions were not found in every rat given a dose level of 1000, 2000, 4000, and $8000 \mathrm{mg} / \mathrm{kg}$ BW. This condition showed that the administration of jernang resin extracts to Sprague dawley white rats did not cause any toxic symptoms as seen from observations of activity, gastrointestinal, gastrourinary, and muscular nerves.

\section{d. $L D_{50}$ determination}

The observations made in the determination of $\mathrm{LD}_{50}$ were seen based on the number of deaths in rats that had been given jernang resin extract treatment with several dosage levels. The $\mathrm{LD}_{50}$ acute toxicity test aims to determine the level of toxicity of a compound. The results of tests on rat mortality for grading doses of jernang resin extracts were presented in Table 3 .

Based on observations for 14 days only 1 rat was found dead at a dose rating of $1000 \mathrm{mg} / \mathrm{kg}$ body weight. But it was suspected that the death of the rat was not caused by the administration of jernang resin extracts, because this occurred in the group of rats given the lowest dose of $1000 \mathrm{mg} / \mathrm{kg} \mathrm{BW}$. These results indicated that jernang resin extracts with a dose of $8000 \mathrm{mg} / \mathrm{kg}$ body weight can be categorized as safe for consumption because no deaths were found in test animals. 
TABLE 3 .

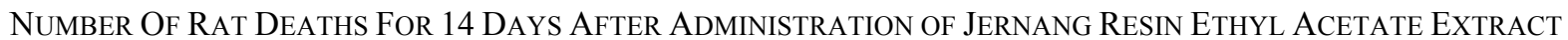

\begin{tabular}{cccc}
\hline Jernang resin extract dose $(\mathbf{m g} / \mathbf{k g ~ B W})$ & $\begin{array}{c}\text { The number of animals } \\
\text { per group }\end{array}$ & Dead animal & Living animals \\
\hline 0 & 5 & 0 & 5 \\
1000 & 5 & 1 & 5 \\
2000 & 5 & 0 & 5 \\
4000 & 5 & 0 & 5 \\
8000 & 5 & 0 & 5 \\
\hline
\end{tabular}

The results of acute toxicity testing are influenced by several factors such as species, individual diversity, sex, age, body weight, mode of administration, animal health, and the environment [15].

Non-toxic jernang resin extracts have also been proven by Jia (2014). In that study, a toxicity test was carried out in rabbits. Based on these studies, jernang resin extracts did not have toxic effects on rabbits and did not cause damage to the liver and kidneys of guinea pigs [16]

\section{e. Changes in Rat Organs}

\section{Macroscopic Rat Heart}

The liver is an organ that has the potential to experience damage due to chemicals that enter the body because the liver plays a role in the process of metabolism and detoxification. The way the liver works in detoxifying poisons is by breaking down toxic compounds into several compounds such as urea, ammonia, and uric acid [17]. The function of liver as detoxification of these poisons has consequences that the liver becomes very vulnerable to damage due to toxic substances. The rat liver has more than one lobe (multilobus) as in other mammals.
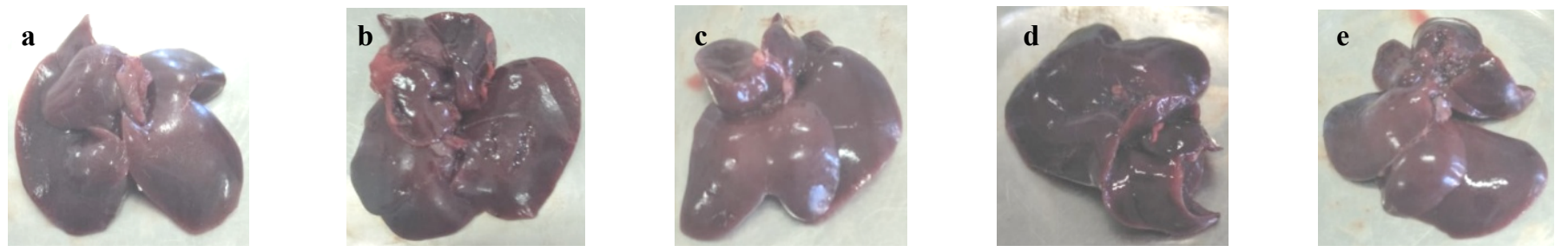

Fig 3. Morphology of rat liver after administration of jernang resin ethyl acetate extract, Control (a), Dose $1000 \mathrm{mg} / \mathrm{kg}$ BW (b),

Dose 2000 mg/kg BW (c), Dose 4000 mg/kg BW (d), Dose 8000 mg/kg body weight (e)

In Figure 3, the control group with doses of 1000, 2000, 4000 and $8000 \mathrm{mg} / \mathrm{kg} \mathrm{BW}$ did not change color, which was brownish-red, slippery surface and did not show any abnormalities. This is consistent with the opinion of Lailatul et al. (2015) which states that a normal heart has a brownish-red color [18].

Descriptively the administration of jernang resin extracts to Sprague Dawleyon white rats did not show a different macroscopic picture of the liver. Liver damage due to toxic substances is influenced by several factors, such as the type of chemical involved, the dose given, and the duration of exposure to such substances as acute, subchronic, or chronic [19].On the other hand, the liver has a high regeneration ability. Tissue loss due to toxic substances stimulates the mechanism by which liver cells begin to divide and continue until tissue mass repair is achieved [20].

\section{Macroscopic Rat Kidney}

Kidneys are very efficient organs in the process of eliminating toxic substances from the body. High blood flow from the kidneys and increased concentrations of excreted products followed by water reabsorption from the tubular fluid are the main factors involved in influencing the sensitivity of the kidneys to these toxic substances [21]. In this examination, the physical condition of the organ was compared with a normal kidney. In the treatment group doses of 1000, 2000, 4000 , and $8000 \mathrm{mg} / \mathrm{kg}$ body weight compared with the control group, the results descriptively did not show differences in the macroscopic appearance in the kidney (Figure 4).

The existence of changes in the color of the organs can be one of the parameters of a toxic effect. This was related to the strategic function of the kidneys which is destroying certain toxic substances, thus making the kidneys as the main target of toxic effects [13]. 

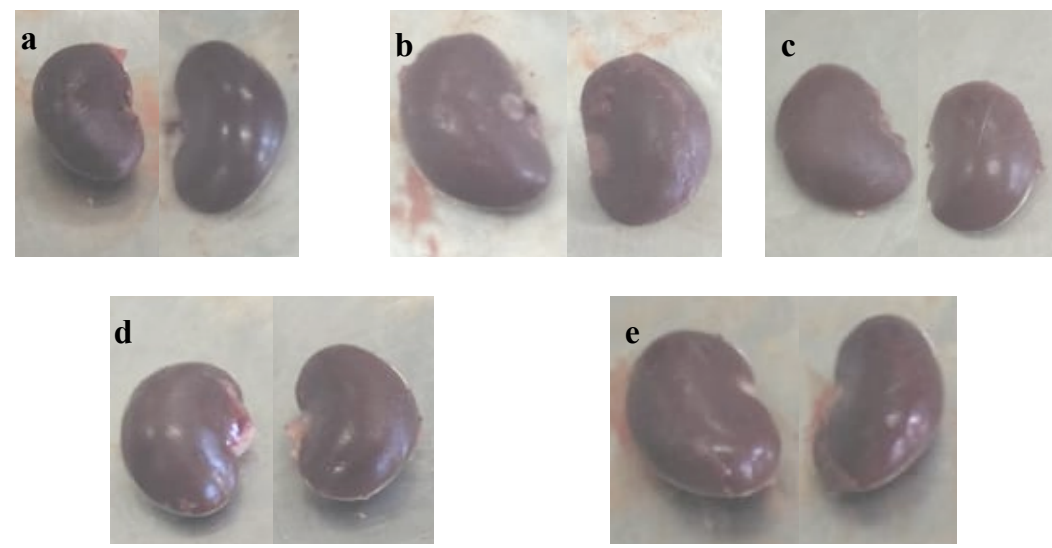

Fig 4. Macroscopic kidney organ of rats after administration of jernang resin ethyl acetate extract, Control (a), Dose $1000 \mathrm{mg} / \mathrm{kg}$ body weight (b), Dose $2000 \mathrm{mg} / \mathrm{kg}$ body weight (c), Dose $4000 \mathrm{mg} / \mathrm{kg}$ body weight (d), Dose $8000 \mathrm{mg} / \mathrm{kg}$ body weight (e)

\section{Weighing Rat Organ Weight}

Data on the average weight resulted of the rat liver after treatment could be seen in Fig 5. From these results, it could be seen that the highest average organ weight was found in the group with a dose of $8000 \mathrm{mg} / \mathrm{kg}$ body weight, this was due to the rat's weight in this group was greater than the other groups. Liver mass in rats represents about $5 \%$ of the total body weight of these rats [22]. So the higher the weight of the rat, the weight of its organs becomes larger. It can be categorized that the liver weight of experimental rats was within the normal range. Treatment of doses of jernang resin extracts of $1000,2000,4000$, and $8000 \mathrm{mg} / \mathrm{kg}$ body weight can still be responded to well by the body of the rat, which after entering the bloodstream, which will then be taken to the liver. All substances carried by the blood will be synthesized into simpler molecules that are ready to be circulated throughout the body.

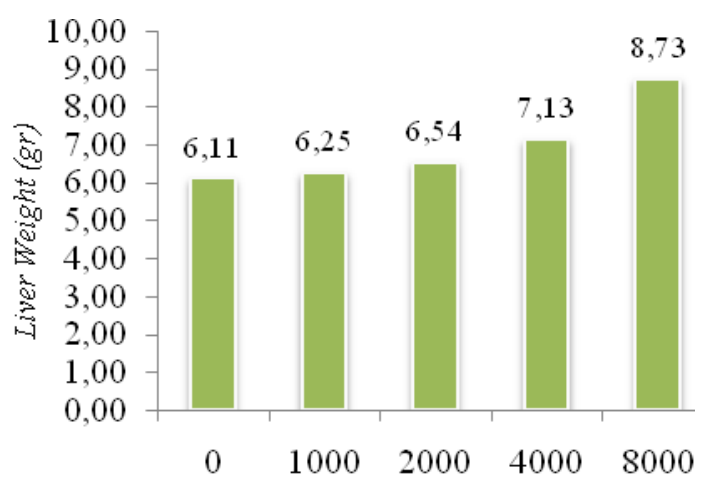

Doses $(m g / k g B B$

Fig 5. Graph of liver weight in rats

Giving jernang resin extract did not provide heavy work for the liver so that liver function can run normally and did not affect the weight of the liver. The liver weight ratio did not change so significantly that the animals given the variation of

doses had the same liver weight ratio with the control group. So that the administration of jernang resin extract had no influence or toxic effect on the ratio of the weight of the liver.

TABLE 4.

AVERAGE VALUES OF RAT LIVER AND KIDNEY WEIGHT AFTER ADMINISTRATION OF JERNANG RESIN ETHYL ACETATE EXTRACT

\begin{tabular}{ccc}
\hline $\begin{array}{c}\text { Dose } \\
(\mathbf{m g} / \mathbf{k g ~ B W})\end{array}$ & $\begin{array}{c}\text { Unwilling } \\
(\mathbf{g r})\end{array}$ & $\begin{array}{c}\text { Kidney } \\
\text { weight } \\
\mathbf{( g r )}\end{array}$ \\
\hline 0 (Control) & $6,11^{\mathrm{a}}$ & $0,61^{\mathrm{a}}$ \\
1000 & $6,25^{\mathrm{a}}$ & $0,62^{\mathrm{a}}$ \\
2000 & $6,54^{\mathrm{a}}$ & $0,65^{\mathrm{a}}$ \\
4000 & $7,13^{\mathrm{a}}$ & $0,63^{\mathrm{a}}$ \\
8000 & $8,73^{\mathrm{b}}$ & $0,89^{\mathrm{b}}$ \\
\hline
\end{tabular}

The relative weight of the kidney can be used as an indication of kidney damage. The measurement results of the average rat kidney weight can be seen in Fig 6. In the calculation results statistically (Table 4) it can be seen that the rat kidney weight ratio was significantly different in the control group, 1000, 2000, 4000, with the treatment group dose of $8000 \mathrm{mg} / \mathrm{kg} \mathrm{BB}$. Kidney weight according to rat weight, where the lowest kidney weight was found in the control group with an average body weight of 160.56 grams. While the highest kidney weight was found in the treatment group with a dose of $8000 \mathrm{mg} / \mathrm{kg} \mathrm{BW}$ with an average rat bodyweight of 214.73 grams. According to Linder (1992), stated that the relative weight of rat kidneys is $0,4-0,9 \%$ of the bodyweight of rats [23]. So from these data, it can be concluded that the kidney weight of experimental rats is still in the normal weight category. 


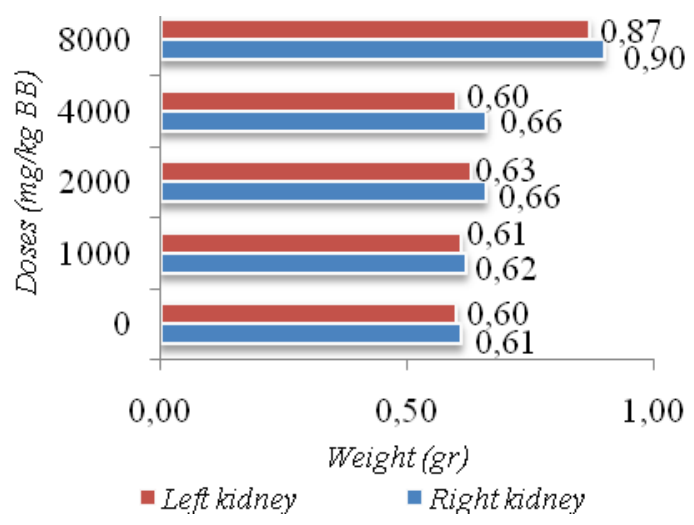

Fig 6. Graph of kidney organ weight in rats.

\section{CONCLUSION}

Based on the results of this research that has been done, it can be concluded that:

1. The application of jernang resin extracts (Daemonorops Draco Willd.) on Sprague Dawleymale white rats did not cause toxic effects, this was seen from total consumption, weight gain, clinical symptoms, $\mathrm{LD}_{50}$ values, and observations of organs (liver and kidney).

2. Acute toxicity test of jernang resin extract (Daemonorops Draco Willd.) on Sprague Dawleymale white rats with the highest dose of $8000 \mathrm{mg} / \mathrm{kg}$ body weight were considered safe for consumption because it tend to accelerate the growth of rats and did not cause harm its metabolic organs in all groups of experimental animals.

\section{ACKNOWLEDGMENT}

We would like to thank anybody who support the works .

\section{REFERENCES}

Saifuddin, Nahar dan Diana Selvie. 2016. Pengaruh Perbedaan Kepolaran Pelarut Pada Ekstraksi Resin Dari Buah Jernang (Dragon Blood) Metode Masearasi UntukPenentuan Kualitas Resin Jernang Sesuai SNI 1671:2010.Prosiding SNTK UNIMAL. 17 OKTOBER 2016.

[2] Asra, R., Syamsuardi, S., Mansyurdin, M., \& RidhoWitono, J. 2012 Rasio Jernang (Daemonorops DracoWilld.) blume) Pada Populasi Alami Dan Budidaya: Implikasi Untuk Produksi Biji. Botanic Gardens Bulletin,15(1), 1-9.

[3] Purwanto Y, Polosakan R, Susiarti S, dan Walujo E.2005. Ekstraktivisme Jernang (Daemonorops spp) dan Kemungkinan Pengembangannya. Laporan Teknik.Bidang Botani, Pusat Penelitian Biologi-LIPI.Bogor.

[4] Donatus IA. 2001. Toksikologi Dasar. Laboratorium Farmakologi dan Toksikologi. UGM Press, Yogyakarta.

[5] Siregar, P.H. 2005. Isolasi flavonoida dari daun tumbuhan kemuning (Murraya paniculata (L.) Jack). Jurnal Sains Kimia $9(3): 12-14$
[15] Balls M, James B, Jacqueline. 1995. Animals And Alternatives in Toxicology. Great Britain at the University Press. Cambridge.

[16] Jia, Y.F., Chui, M.S., Zhu, L.,Wan, L.P., Ya, Z.Z., Zhong, Z.Z., \& Hu, B.C. (2014). A systematic review of the botanical, phytochemical and pharmacological profile of Dracaena cochinchinensis, a plant source of the ethnomedicine "Dragon's Blood". Molecules 19, 10650-10669.

[17] Sudatri, IW, Setyawati I, Suartini NM, Yulihastuti DA. 2016. Penurunan fungsi hati tikus betina (Rattus norvegivus) yang diinjeksi white vitamin c dosis tinggi dalam jangka waktu lama ditinjau dari kadar sgpt, sgot serta gambaran histologi hati. Jurnal Metamorfosis. 3(1): 44-51.

[18] Lailatul, N.F., Diana L.Y. dan Mudjiwijono H. 2015. Efek pemberian asam alfa lipoat terhadap kadar MDA dan gambaran histologi pada hati tikus model diabetes melitus tipe 1. Jurnal Kedokteran Brawijaya. 28(3): 170-177.

[19] Darmansjah I, Wiria MSS. 2007. Dasar Toksikologi.In: Gunawan SG, Setiabudy R, Nafrialdi, Elysabeth.. Farmakologi dan Terapi. $5^{\text {th }}$ ed. Departemen Farmakologi dan Terapeutik Fakultas Kedokteran Universitas Indonesia: Jakarta. (5):820.

[20] Junqueira, LC dan Cameiro J. 1997. Histologi Dasar. $3^{\text {th }}$ ed. EGC: Jakarta

[21] Hodgson, J dan Levi. 2002. Regular inggestion of black tea improves brachialartery vasodilator function. Clinsci (Lond). 102: 195-201

[22] Martins, P.N dan Peter Neuhaus. 2007. Surgical anatomy of the liver, hepatic vasculature and bile ducts in the rat. Departmentof General-Visceral and Transplatation Surgery, Virchoe Clinic, Charite University Medicine Berlin, Germany.

[23] Linder, MC. 1992. Biokimia Nutrisi dan Metabolisme: dengan Pemakaian Secara Klinis. UI Press: Jakarta. 